DOI https://doi.org/10.30525/978-9934-26-075-9-12

\title{
ВПРОВАДЖЕННЯ НОВІТНІХ НАУКОВИХ МЕТОДІВ СУДОВО-МЕДИЧНОЇ ДІАГНОСТИКИ ДАВНОСТІ ЗАПОДІЯННЯ МЕХАНІЧНОЇ ТРАВМИ
}

\author{
Ергард Н. М. \\ кандидат медичних наук, доцент, \\ доцент кафедри судової медицини та медичного права \\ Національний медичний університет імені О. О. Богомольия
}

\section{Кубаля С. М.}

лікар судово-медичний експерт лівобережного відділення відділу експертизи трупів

Київське міське клінічне бюро судово-медичної експертизи Міністерства охорони здоров'я Украӥни

\section{Ситник Ю. В.}

лікар судово-медичний експерт лівобережного відділення відділу експертизи трупів

Київське міське клінічне бюро судово-медичної експертизи

Міністерства охорони здоров'я України

\section{Богдаш В. В.}

лікар судово-медичний експерт лівобережного відділення відділу експертизи трупів

Київське міське клінічне бюро судово-медичної експертизи

Міністерства охорони здоров'я України

\section{Селін В. С.}

лікар судово-медичний експерт лівобережного відділення відділу експертизи трупів

Киїське міське клінічне бюро судово-медичної експертизи

Міністерства охорони здоров'я України

м. Київ, Украӥна

Судово-медична експертиза пов’язує діяльність медичної сфери із правосуддям України. В межах проведення судово-медичної експертизи вирішуються ряд питань, пов'язаних із давністю настання смерті, 
причинами смерті, ступенем тяжкості тілесних ушкоджень тощо. Враховуючи те, що кількість летальних випадків збільшилась внаслідок різних видів механічних травм, то і питання давності їх заподіяння залишається і досі актуальним.

Давність заподіяння травми за місцевими проявами організму досліджувались не одне десятиріччя, наукові розробки стосувались змін на клітинному рівні, визначали й особливості розвитку судинної динаміки при травмі, також були дослідження динаміки морфологічних змін та змін вмісту фізіологічно-активних речовин. [1,2].

Однак, проявам системної реакції організму на травму приділяли незначну увагу. Звісно, деякі дослідження системної реакції організму на травму проводились науковцям. Так, наприклад, доведено підвищення вмісту катехоламінів в периферійній крові при травмах у порівнянні 3 ненасильницькою смертю, а також зміни на рівні нейроендокринної системи при гострій травмі, що супроводжувалась розвитком загального адаптаційного синдрому та розвитком стресу. [3, 4]. Проте, поруч із зазначеними здобутками залишаються невирішеними ще безліч питань.

Необхідно зазначити, що одну із головних ролей в адаптації організму при отримані механічної травми відіграють надниркові залози. Саме в корі надниркових залоз відбуваються морфологічні зміни пов'язані із утворенням зон ліпідизації та деліпідизації. Були наукові розробки, які довели збільшення зон деліпідизації кори надниркових залоз по відношенню до зон ліпідизації при смерті внаслідок повішення в порівнянні із зонами деліпідизаці/ліпідизації при смерті від хронічної ішемічної хвороби серця. [5]. Проте, не було наукових робіт направлених на дослідження площі деліпідизації/ліпідизації та коефіцієнту їх співвідношення при смерті внаслідок механічної травми в різні проміжки часу. Науковий напрям нашої роботи по вивченню системної реакції організму на травму направлений на дослідження зміни розмірів площі ділянок ліпідизації та деліпідизації кори надниркових залоз у трупів осіб, смерть яких настала від механічної травми безпосередньо після травми 3 мінімальною тривалістю перебігу, за короткий проміжок часу (в межах десятків хвилин) та в межах 1-2 годин, що дасть можливість більш точно встановити давність їі заподіяння.

Слід зауважити, що пандемія нової коронавірусної інфекції COVID19, також внесла свої корективи у диференційну діагностику між гострим респіраторним дистрес-синдромом при травмі та при COVID-19. Дослідження науковців показало, що основним морфологічним субстратом ураження легень $є$ дифузне альвеолярне ураження із залучення у патологічний процес судинного русла легень. Так, при COVID-19 
патологія судин легень проявляється ушкодженням ендотелію, ендотеліїт та васкуліт $з$ тромбозами судин різного калібру, а також тромбемболією легеневої артерії та інфарктом легень. Такі патологічні зміни призводять до розвитку гострого респіраторного дистрес-синдрому. Схожа картина спостерігається і при тяжких травмах, що супроводжуються шоковими станами з розвитком «шокової легені». Однак, навідміну від травми, при COVID-19 спостерігається й ураження судинного русла [6, 7]. Тяжкі травми можуть супроводжуватися шоковими станами 3 розвитком гострого респіраторного дистрес-синдрому чи «шокової легені». Розвиток вказаних станів обумовлений системною реакцією організму на такий сильний подразник як травма. Однак, з розвитком поліорганної недостатності розвивається й сепсис. Багато наукових робіт серед лікарівтравматологів було присвячено диференційній діагностиці між синдромом системної відповіді на запалення (SIRS) неінфекційного генезу та сепсисом у тяжкохворих пацієнтів. [8]. Авторами було акцентовано увагу на доцільності дослідження прокацьцитоніну для встановлення своєчасного диференційного діагнозу між тяжким SIRS бактеріального та небактеріального генезу. Науковці виявили підвищення його рівня при системній запальній реакції, політравмі, розвитку септичних ускладнень. $[8,9]$. Враховуючи те, що для важких травм характерний розвиток гострого респіраторного дистрес-синдрому чи «шокової легені», а прокальцитонін синтезується також і в нейроендокринних клітинах легень під впливом прозапальних стимуляторів, то його можна використовувати як маркер ранньої діагностики системної запальної реакції (шок нез'ясованого генезу, травми), тому дослідження змін прокальцитоніну в плазмі крові трупів осіб, смерть яких настала від механічної травми $з$ різною тривалістю вмирання $є$ доцільним та актуальним для встановлення давності іï заподіяння. Це є ще одним нашим науковим напрямом дослідження.

Отже, актуальність та практична значимість судово-медичної діагностики давності заподіяння травми в ранній антемортальний період, необхідність розробки нових діагностичних критеріїв для визначення системної реакції організму на травму і обумовило необхідність глибокого та всебічного вивчення вищезазначеної проблеми. Наукові дослідження площі деліпідизації/ліпідизації, коефіцієнту їх співвідношення і зміни прокальцитоніну в плазмі крові при смерті внаслідок механічної травми саме в різні проміжки часу та розробка діагностичних критеріїв допоможуть, у майбутньому, судово-медичному експерту визначати давність заподіяння травми в більш короткі проміжки часу, а також підвищать ефективність судово-медичної діагностики визначення тривалості 
перебігу травматичного процесу в ранній термін антемортального періоду 3 метою уніфікації результатів дослідження та уникнення діагностичних помилок.

\section{Література:}

1. Noriaki I. Postmortem interval estimation - for better understanding of postmortem changes. Current issues of forensic medicine and expert practice - 2020: materials of the internationsl cong. (Moscow, 15-17 April 2020). Moscow, 2020. C. 8-9.

2. Фролова И. А. Значение гистологического метода исследования в определении давности повреждения мягких тканей. Судебная медищина. 2016. T. 2, № 2. C. 143-144.

3. Біляков А. М. Визначення діагностичних критеріїв для встановлення травматичного генезу смерті та тривалості перебігу смертель= ної механічної травми за коефіцієнтом співвідношення вмісту ефіри холестерину /холестерин в тканині наднирників людини. Вісн. Вінниц. наи. мед. ун-ту ім. М. І. Пирогова. 2013. Т. 17, № 1. С. 8-10.

4. Туманов Э. В., Кильдюшов Е. М., Ермакова Ю. В., Кузнецова Г. С. Диагностика давности наступления смерти в позднем посмертном периоде в судебно-медицинской практике (обзор литературы). Судебномедииинская экспертиза. 2018. Т. 4, № 1. С. 34-38.

5. Ергард Н. М. Судово-медичне визначення зажиттєвості повішення за кількісною оцінкою стероїдогенезу глюкокортикоїдів у надниркових залозах: автореф. дис. ... канд. мед. наук: 14.01.25. Харків, 2017. 20 с.

6. Забозлаев Ф. Г., Кравченко Э. В., Галлямова А. Р., Летуновский Н. Н. Патологическая анатомия легких при новой коронавирусной инфекции (COVID-19). Предварительный анализ аутопсийных исследований . Клиническая практика. 2020. Т. 11, № 2. С. 21-37.

7. Зайратьянц О. В., Самсонова М. В., Черняев А. Л., Мишнев О. Д., Михалёва Л. М., Крупнов Н. М., Калинин Д. В. Патологическая анатомия COVID-19: опыт 2000 аутопсий. Судебно-медицинская экспертиза. 2020. T.6, № 4. C. 10-23.

8. Zheng M., Gao Y., Wang G., et al. Functional exhaustion of antiviral lymphocytes in COVID-19 patients. Cell Mol Immunol. 2020. Vol. 17, No. 5, P. 533-535.

9. Эделев Н. С., Воробьев В. Г., Эделев И. С. Применение биохимических методов исследования при решении вопросов судебномедицинской практики. Судебно-медищинская экспертиза. 2019. Т. 62, № 4. С. 63-67. 